\title{
海象計における種々の波動量の組合せによる 方向スペクトル推定精度の比較 ESTIMATION ACCURACY OF DIRECTIONAL SPECTRUM BASED ON THE SEVERAL COMBINATION OF WAVE SIGNAL WITH DOPPLER TYPE DIRECTIONAL WAVE METER
}

\author{
岩崎裕志 $1 \cdot$ 横田雅紀 ${ }^{2} \cdot$ 橋本典明 $3 \cdot$ 三井正雄 $4 \cdot$ 河合弘泰 5 \\ Hiroshi IWASAKI, Masaki YOKOTA, Noriaki HASHIMOTO, \\ Masao MITSUI and Hiroyasu KAWAI
}

\footnotetext{
1学生会員 九州大学大学院工学府海洋システム工学専攻 († 819-0395 福岡県福岡市西区元岡744)

2正会員 工修 九州大学助教 工学研究院環境都市部門 (₹ 819-0395 福岡県福岡市西区元岡744)

3フェロー 博(工)九州大学教授 工学研究院環境都市部門 ( 78190395 福岡県福岡市西区元岡744)

4理修（株)ソニック＼cjkstart海象機器部（１１90-1295東京都西多摩郡瑞㯖町箱根ヶ崎東松原19-6)

5 正会員＼cjkstart博（工）（独）港湾空港技術研究所＼cjkstart海洋情報研究領域（２39-0826＼cjkstart横須賀市長瀬3 1- 1)
}

\begin{abstract}
For the improvement of data acquisition of directional wave spectra measured with Doppler-type directional wave meter, we examined possibility and accuracy of directional wave spectrum estimation under various conditions including missing observation data, i.e., water surface elevation or one of the three water particle velocity components with an inclination angle of 30 degrees. As a result, we confirmed it was possible to estimate accurate directional spectra even for the cases including missing data. For example, when water surface elevation is missing due to existence of air bubbles, pressure data measured at the bottom can be used as an auxiliary data for the directional spectral estimation. For the case where one of the three water particle velocity components is missing, accurate directional spectrum can be estimated from the combination of water surface elevation and the remaining two water particle velocity components under the condition where the significant wave height is higher than $1.5 \mathrm{~m}$.
\end{abstract}

Key Words : Directional spectrum,bayesian method, doppler type directional wave meter

\section{1 ・はじめに}

全国港湾海洋波浪情報網(NOWPHAS)で観測され た波浪情報は我が国の沿岸域における防災・環境・ 利用に関連した各種事業及び調査研究に幅広く活 用されている.1995年に波向観測を目的として開発， 実用化された海底設置型の超音波式波高計である 海象計は現在のNOWPHASにおける主要な観測機 器となっている ${ }^{1)}$.

しかしながら暴浪時には, 砕波に伴い表面付近に 巻き込まれた気泡の混入による超音波の散乱のた め, 正常な波形記録を計測できず欠測となる場合が ある.また，まれではあるが津波の来襲や生物との 接触により計器光のものやデータ転送ケーブルに 何らかのトラブルが発生し, 一部の波動量のみが欠 測となる可能性もある．ただし，水面変動データが 欠測となる場合であっても，同時に計測している水 中の水粒子速度の観測層まで気泡が混入していな いケースであれば, 併せて取得している水圧変動デ
一タを利用することにより方向スペクトルの推定 が可能である゙．また，一部の波動量が欠測となっ た場合についても水面変動及び取得されている光 の他の水粒子速度成分のみにより方向スペクトル の推定ができる可能性がある .

本稿では，今後の波浪観測の測得率の向上を目的 として，室津を例に海象計で取得されたデータを用 い, 気泡混入により水面変動の観測データが欠測し た条件を想定し，水面変動のデータを使用せず，水 圧データ及び水中の水粒子測度のみを用いて方向 スペクトルの推定を行った場合，さらに一部の波動 量を欠測とした条件を想定し，3方向で取得してい る水粒子測度のうち一方向を使用せずに方向スペ クトルの推定を行った場合について水面変動及び3 方向の水粒子速度を使用して推定された方向スペ クトルと比較し，推定精度について検討した結果を 報告するものである . 


\section{2 . 計測機器の概要}

海象計は水深 $50 \mathrm{~m}$ 程度の沖合に設置が可能な海 底設置型の計測機であり, 設置水深における水圧変 動に加えて，鉛直上方に射出される超音波により水 面変動を, 鉛直軸より角度 30 傾けて3方向に射出さ れる超音波により, 上, 中, 下層の水粒子速度を計 測している 図 - 1). 水粒子速度を計測する超音波 の水平射出角度は北を $0^{\circ}$ とした時計回りで $0^{\circ}, 120^{\circ}$ ， $240^{\circ}$ である. これらのデータのうち水面変動から有 義波高と周期を，水面変動 子速度 $(\mathrm{u}, \mathrm{v}, \mathrm{w})$ から波向および方向スペクトルを推 定し，リアルタイムに情報を提供している．

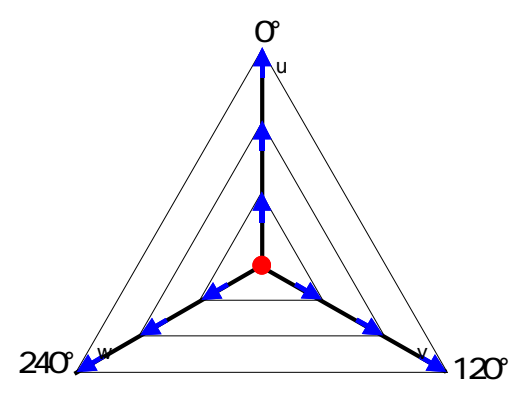

図- 1 海象計による波動量計測のイメージ

海象計による波浪観測における欠測の発生頻度 の例として 11 地点について 2007 年の 1 年間における 2時間間隔のデータ 4380データ)を対象とした有義 波高の欠測頻度を表-1に示す . 欠測の頻度は低いも のの高波浪時に欠測となっている例もあり，気泡混 入の影響を受けたものと考えられる .

\begin{tabular}{c|r} 
表- 1 有義波高の欠測頻度 \\
\hline & \multicolumn{1}{|c}{ 頻度(\%) } \\
\hline 金沢 & 2.35 \\
\hline 富山 & 0.84 \\
\hline 久慈 & 0.68 \\
\hline 潮岬 & 5.71 \\
\hline 鳥取 & 0.41 \\
\hline 室津 & 0.39 \\
\hline 玄界灘 & 4.36 \\
\hline 志布志湾 & 2.37 \\
\hline 苫小牧 & 1.00 \\
\hline 留萌 & 2.51 \\
\hline 中城湾 & 1.80 \\
\hline \multicolumn{2}{|l}{}
\end{tabular}

\section{3. 解析手法}

本検討では種々の波動量を用いた方向スペクト ルの推定にあたり，ベイズ法を用いることとした ${ }^{3)}$.
ベイズ法については以下に詳述する .

微小振幅波理論では, 水面変動, 水圧変動, 水面 勾配, 水粒子速度などの任意の波動量は光れらの波 動間量の伝達関数を用いて互いに変換できる ${ }^{4)}$.今， 極座標系を用いれば，座標 $(\alpha, \beta, r)$ 方向での $r$ 方向 の水粒子速度 $U$ と, 中心位置直上の水面変動 $\eta$ は, 次式の伝達関数で関係付けられる.

$$
\begin{aligned}
& H\left(\alpha, \beta, r_{0}, \Delta r, d, z_{0} ; \omega, \theta\right) \\
& =\frac{-i \omega \exp (-i \omega \Delta t)}{\Delta r k \sinh k d}\left[\cosh \left\{k\left(r \cos \alpha+z_{0}\right)\right\}\right. \\
& \times \exp \{i k r \sin \alpha \cos (\theta-\beta)\}]_{r_{0}-\Delta r / 2}^{r_{0}+\Delta r / 2}
\end{aligned}
$$

ここに, $d$ は水深, $k$ は波数, $\omega$ は角周波数, $\theta$ は 波の伝播方向， $z_{0}$ は海底からの機器設置高， $\Delta t$ は 各方向の水粒子測度成分 $U$ と水面変動 $\eta$ との計測 時刻のずれ， $\Delta r$ は反射して戻ってきた超音波信号の $r$ 方向の切り取り長さである . また,$r_{0}$ は炎の中心 位置である .

この伝達関数を用いると波動量 $\xi_{m}(t)$ と $\xi_{n}(t)$ との クロススペクトル $\Phi_{m n}(f)$ と方向スペクトル $S(f, \theta)$ は次式の積分方程式で関係づけられる .

$$
\Phi_{m n}(f)=\int_{0}^{2 \pi} H_{m}(f, \theta) H_{n}{ }^{*}(f, \theta) S(f, \theta) d \theta
$$

ここに， $H_{m}(f, \theta)$ は式(1) を略記したものであり， 波動量 $\xi_{m}(t)$ から中心位置での水位変動 $\eta(t)$ への伝 達関数を表し， ${ }^{*}$ は共役複素数を表す．なお， $\xi_{m}(t)=\eta(t)$ の場合には $H_{m}(f, \theta)=1$ である .

方向スペクトルの推定は,式(2)で与えられるクロ ススペクトルに関する連立積分方程式の非負の解 を求めることにより推定される .

式(2)に基づいて方向スペクトルを推定する方法 にはいくつかの方法があるが , ベイズ法では方向分 布関数に次式の離散的一定值関数

$$
G(\theta / f) \approx \sum_{k=1}^{K} \exp \left\{z_{k}(f)\right\} I_{k}(\theta)
$$

を仮定している． $K$ は, 方向分布関数の定義域 $[0,2 \pi]$ を等分割数した值である .ここに，

$$
I_{k}(\theta)=\left\{\begin{array}{l}
1:(k-1) \Delta \theta \leq \theta<k \Delta \theta \\
0: \text { otherwise }
\end{array}\right.
$$

である.式(2)に含まれる未知パラメータ $\left\{z_{k}\right\} か ゙$ 決ま れば $G(\theta / f)$ が決まるが，一般に未知パラメータ数 は，観測して得られる式(1)の数より多く, 非適切な 逆問題になる.乥こで $G(\theta / f)$ が方向角に対してな めらかな連続関数であるとして，系列 $\left\{z_{k}\right\}$ が局所的 には $k$ に関する 1 次式で近似できると仮定する．す 
なわち，

$$
\sum_{k=1}^{K}\left(z_{k}-2 z_{k-1}+z_{k-2}\right)^{2} \quad ;\left(z_{0}=z_{K}, z_{-1}=z_{K-1}\right)
$$

を考えると, 式(5)の値が小さいほど $G(\theta / f)$ はなめ らかになる。したがって， $G(\theta / f)$ の推定値として は式(5)をあまり大きくしない範囲で, $\left\{z_{k}\right\}$ に関する 尤度が大きいものか望ましい .これを定式化すると， 適当なパラメータ $u^{2}$ を用いて，

$$
\sum_{j=1}^{J}\left\{\Phi_{j}-\sum_{k=1}^{K} \alpha_{j, k} \exp \left(z_{k}\right)\right\}^{2}+u^{2}\left\{\sum_{k=1}^{\mathrm{K}}\left(z_{k}-2 z_{k-1}+z_{k-2}\right)^{2}\right\}
$$

を最小化する $\left\{z_{k}\right\}$ を求めればよい.$J$ は式(2)の方程 式の数を 2 倍した值である.ここに, 式(6)の第 1 項 は式(4)を式(2)に代入して離散化したものである . $u^{2}$ の決定と $\sigma^{2}$ の推定は次式で表される $\mathrm{ABIC}($ 赤池 のベイズ型情報量基準)

$$
A B I C=-2 \ln \int L\left(z_{1}, \Lambda, z_{k} ; \sigma^{2}\right) p\left(z_{1}, \Lambda, z_{k} \mid u^{2}, \sigma^{2}\right) d z
$$

の最小化によって求める .

\section{4. 一方向欠測時の方向スペクトル推定精度}

\section{（1）検討方法}

本章では水面変動データは取得できているもの の, 斜め 3 方向で取得されている波動量のうち 1 方 向のみが欠測した条件での方向スペクトル推定精 度について検討を行なった . 水面変動は取得されて いることから有義波高及び有義波周期は推定可能 であるため，ここではピーク波向の推定精度に着目 する .

\section{(2) 検討結果}

一例として 2009 年 10 月 7 日 1 時における方向ス ペクトルの推定結果を比較したものを図 2 に示す. 図中の 1 段目には水面変動及び 3 方向の上層の計 4 成分の波動量を用いて推定された方向スペクトル を,2〜4段目には斜め 3 方向のうち×印で示す 1 方 向について欠測を仮定し，○印で示す水面変動及び 2 方向の上層の計 3 成分の波動量を用いて推定され た方向スペクトルを示している．方向集中度には若 干の差がみられるものの, 全てのケースで同じ方向 にピークを有しておりこの時刻では一方向が欠測 していても波向が精度良く推定可能であることが わかる .

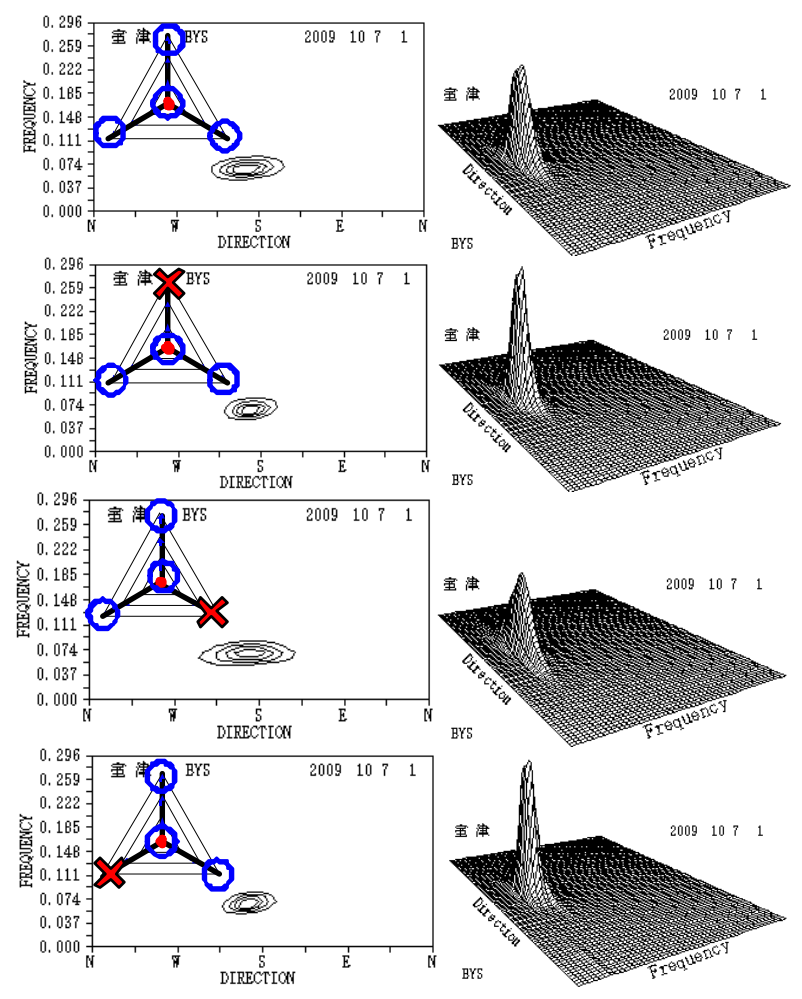

図 2 一方向を欠測としたときの方向スペクトル
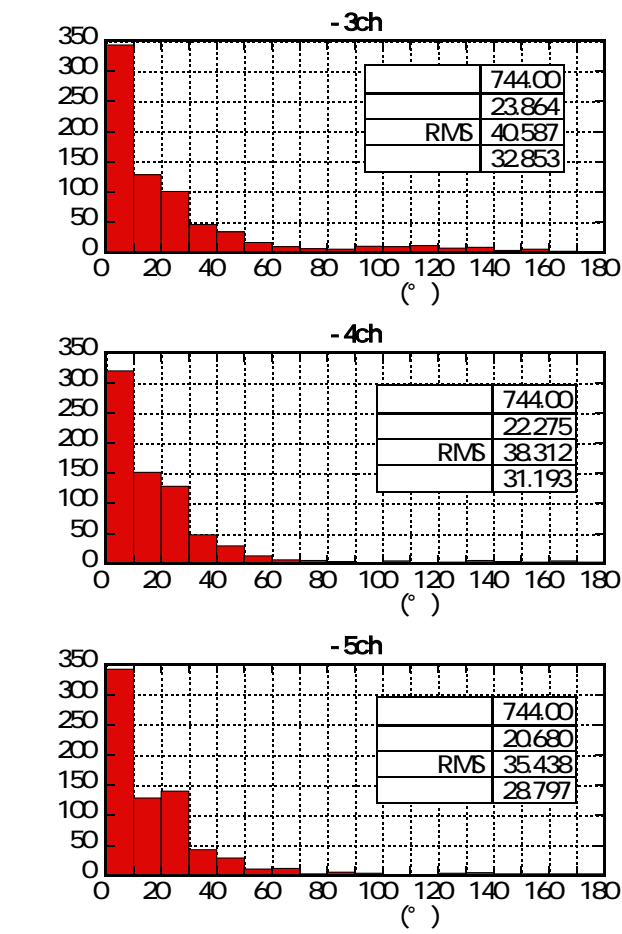

図-3ー方向欠測時におけるピーク波向の推定誤差

図-3 3 は 2007 年 1 月において, 4 成分を用いて推 定されたピーク波向を真值と仮定し，3 成分を用い た場合に推定されたピーク波向との誤差 $\left(^{\circ}\right)$ の発生

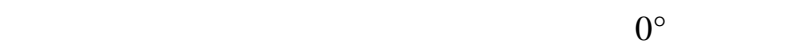
計回りで $0^{\circ}(3 \mathrm{ch})$,中段は $120^{\circ}(4 \mathrm{ch})$,下段は $240^{\circ}(5 \mathrm{ch})$ を欠測としたケースを示している.16 方位での推定 で有意な差を発生させないためには概ね誤差 $10^{\circ}$ 以 
内であることが望まれるが $10 \circ の$ 範囲で推定され たのは半数程度であった .また , チャンネル別にみ ると 4ch 欠測が他の 2 つに比べて若干精度が低くな る傾向が伺える.なお，ここでは示していないが他 の季節についても概ね同樣の傾向がみられた .

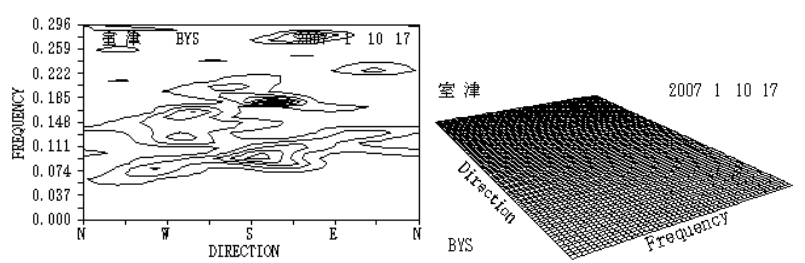

図-4 波向推定誤差の大きい時刻の方向スペクトル例

ここで,ピーク波向の推定誤差が大きかった時刻 の方向スペクトルの一例を図-4に示す.図からピー ク波向の推定精度が低いケースは波高が小さくエ ネルギーの集中が複数の周波数及び方向に分布し ている例であることが推察される .
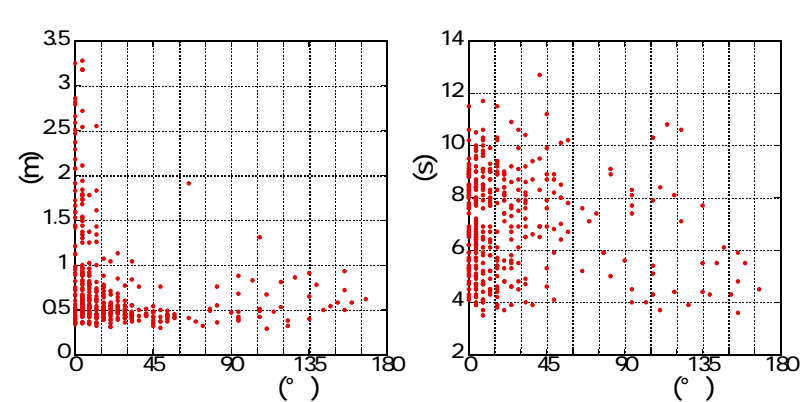

図- 5 波向の推定誤差と有義波高, 有義波周期との比較

図 5 は 2007 年 1 月において, 3ch が欠測とした 場合におけるピーク波向の推定誤差を同時刻にお ける有義波高及び有義波周期と比較したものであ る. 図から有義波高が $1.5 \mathrm{~m}$ 以上のケースに限れば 精度良くピーク波向を推定できていることが分か る . 周期との明瞭な相関関係はみられなかった .

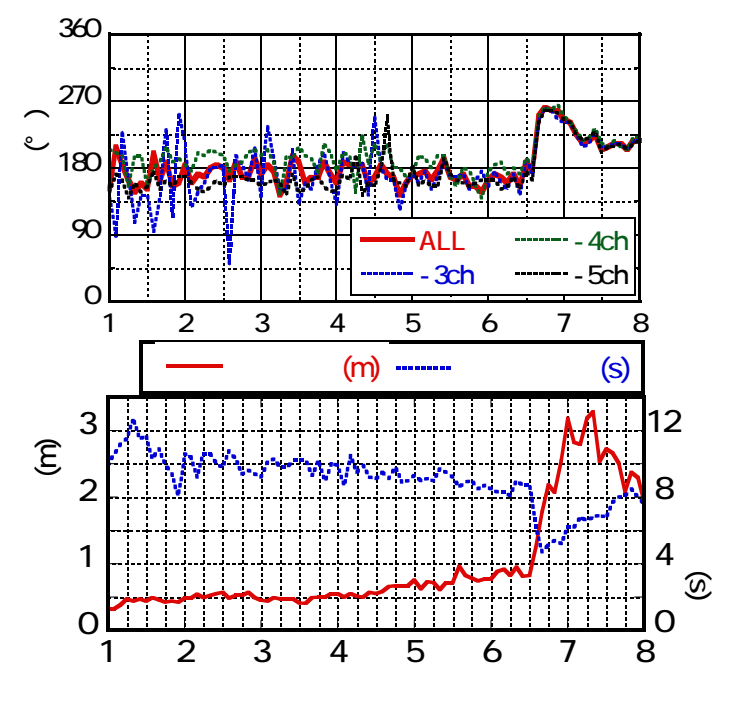

図- 6 ピーク波向及び有義波高，有義波周期の時系列
図- 6 は 2007 年 1 月 1 7 日において 4 種の波動量 の組合せにより推定された方向スペクトルのピー ク波向を時系列で比較したものであり，併せて有義 波高及び，有義波周期の時系列も示している . 図か ら有義波高 $0.5 \mathrm{~m}$ 程度の期間では 3 成分を用いたケ 一スの波向がばらつく傾向にあるが，5 日以降の有 義波高が $0.5 \mathrm{~m}$ を超えて増加し始めるとピーク波向 の誤差が小さくなっていることがわかる .

以上のことから , 斜め 3 方向の波動量のうち 1 方 向が欠測した場合, 静稳時にはピーク波向を精度良 く推定できないが, 波高増大時には推定精度が向上 し，特に有義波高 $1.5 \mathrm{~m}$ 以上のヶースでは精度良く 推定できることが示されたといえる .

\section{5 . 水面変動欠測時の方向スペクトル推定精度}

\section{(1) 検討方法}

暴浪時には砕波に伴い表面付近に巻き込まれた 気泡の混入による超音波の散乱のため, 正常な波形 記録を計測できず欠測となる場合がある .このよう な場合, 水面変動は欠測となるが, 斜め 3 方向にお ける水中の水粒子速度の観測層は上層であっても 海面下 5 15m 付近 (室津では海面下 $15 \mathrm{~m}$ ) を対象 としており，この水深で気泡の混入がなければ，同 時に計測している水圧変動を利用することにより 方向スペクトルの推定が可能である.本章では水面 変動を欠測とする条件で水圧変動及び斜め 3 方向の 水粒子速度を用いた方向スペクトル推定精度につ いて検討を行った。

まず, 水圧変動の周波数スペクトルに以下の式で 与えられる伝達係数を用い, 水面変動の周波数スペ クトルに変換した ${ }^{5)}$.

$$
K=\frac{\cosh k(h+z)}{\cosh k h}
$$
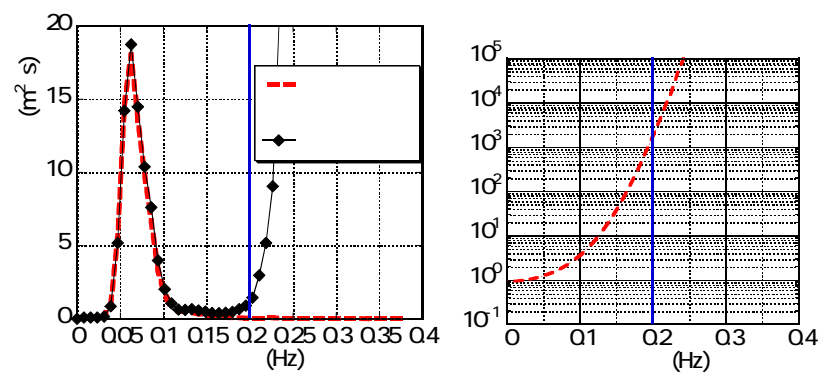

図- 7 周波数スペクトルの推定結果と用いた伝達係数

水圧変動からの変換により求められた周波数ス ペクトル (実線に・のプロット) を水面変動から求 められる周波数スペクトル (破線) と比較したもの を図- 7 左に, 伝達係数の理論值を図- 7 右に示す。 図から周波数 $0.2 \mathrm{~Hz}$ 以下のスペクトル形状は概ね一 致していることがわかる. 海底付近における水圧変 動から高周波数帯のスペクトルを推定するのは困 
難であるため, 周波数 $0.2 \mathrm{~Hz}$ 以下についてのみ上記 の伝達係数による変換を行うものとし， $0.2 \mathrm{~Hz}$ 以上 の周波数についてはエネルギーを持たないものと した。

\section{(2) 検討結果}

2007 年 1 月 1〜7 日について上述の方法により変 換した周波数スペクトルから求めたピーク周波数 の時系列を図-8中にプロットで示す.実線で合わせ て図示している水面変動から求めたピーク周波数 と概ね一致する樣子が伺える.なお, 水圧から変換 した周波数スペクトルではピーク周波数が $0.2 \mathrm{~Hz}$ 以 上の場合ケースは推定できないが, 暴浪時に砕波に 伴って気泡が混入するのは多くの場合ピーク周波 数が $0.2 \mathrm{~Hz}$ 以下と想定される .

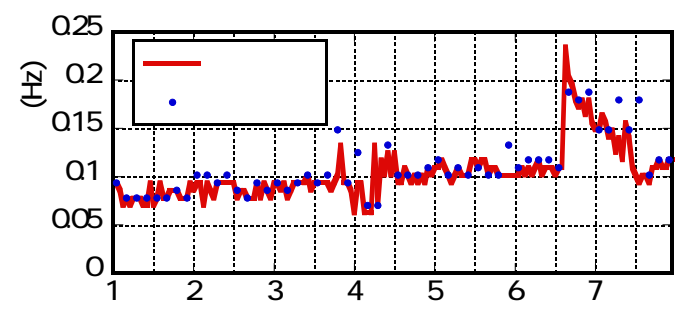

図- 8 ピーク周波数の時系列

図- 9 は 2007 年 1 月において, 水面変動を用いて 推定されたピーク周波数を真值と仮定し, 水圧変動 を変換して得られた周波数スペクトルのピーク周 波数との誤差 $(\mathrm{Hz})$ の頻度分布を整理したものである 誤差が正であれば水面変動のピーク周波数が高く， 負であれば水圧から変換された周波数のスペクト ルのピーク周波数のほうが高いことを意味してい る. 図より，80\%以上のケースでピーク周波数が士 $0.02 \mathrm{~Hz}$ の範囲にあることが分かる.以上のことから 水面変動の周波数スペクトルが概ね精度良く推定 できることから有義波高, 有義波周期については推 定が可能といえる .

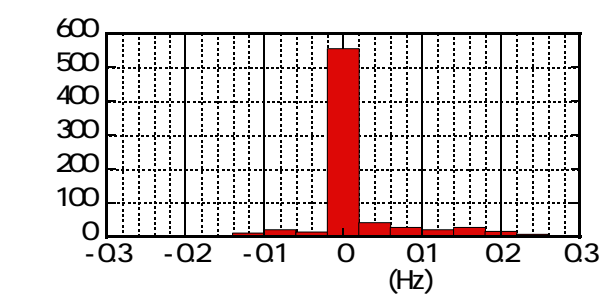

図- 9 ピーク周波数の推定誤差

以下では上述の方法により変換して得られた周 波数スペクトル及び斜め 3 方向の水粒子速度の計 4 成分を用いて方向スペクトル推定を行い, 水面変動 及び斜め 3 方向の水粒子速度の計 4 成分を用いた場 合に推定される方向スペクトルとピーク波向の比 較を行った。

図-10 は推定された方向スペクトルの一例を示し たものである . 上段は水面変動及び斜め 3 方向上層
の水粒子速度を用いた場合，下段は水面変動を欠測 と仮定し, 上述の方法により水圧変動及び斜め 3 方 向の水粒子速度を用いた場合に推定された方向ス ペクトルである . スペクトル形状 , ピーク波向とも にほぼ一致していることが分かる .
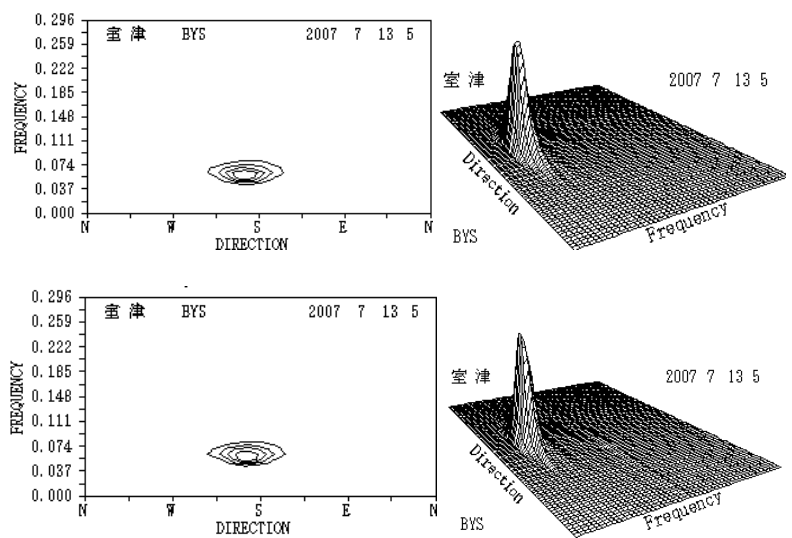

図-10 水圧を用いた方向スペクトル推定の比較

図-11 は 2007 年 1 月において, 水面変動及び斜め 3 方向上層の水粒子速度を用いて推定されたピーク 波向を真值と仮定し, 水圧変動及び斜め 3 方向の水 粒子速度を用いた場合に推定されたピーク波向と の誤差( $\left(^{\circ}\right)$ の発生頻度を整理したものである . 7 割以 上が $\pm 10^{\circ}$ 範囲で推定されており，ピーク波向の推 定精度は高いといえる。

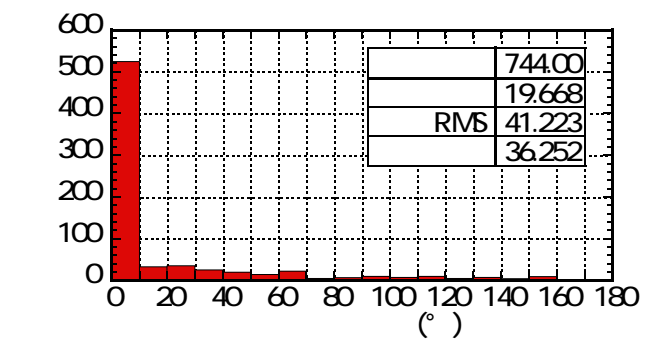

図-11 水面変動欠測時におけるピーク波向の推定

6 .おわりに

本検討では，波浪観測の測得率の向上を目的とし， 気泡混入などにより水面変動の観測データが欠測 した条件及び, 斜め 3 方向のうち 1 方向の水粒子速 度の観測データが欠測した条件で方向スペクトル の推定を行った .

弚の結果，水面変動が欠測する場合でも，斜め 3 方向の水粒子速度が観測されていれば, 水圧変動の データを用いることにより, 波高, 周期, 波向が精 度良く推定できることを明らかにした .

また，斜め 3 方向のうちの 1 方向が欠測となった 場合でも，残る 2 方向の水粒子速度及び水面変動の データから波向を推定可能であり, 波高 $1.5 \mathrm{~m}$ 以上 では十分な精度を有することを明らかにした。 
謝辞：本研究は科学研究費補助金(課題番号: 23360216 , 代表者: 橋本典明) の助成を受けたもの である .

\section{参考文献}

1)橋本典明, 永井紀彦, 高山知司, 高橋智晴, 三井正雄, 磯 辺憲雄, 鈴木敏夫 水中超音波のドップラ一効果を応用し た海象計の開発 海岸工学論文集, 第 42 巻,pp.1081-1086, 1995 .
2)橋本典明,永井紀彦,菅原一晃, 浅井正, 朴慶寿 波浪の 多方向性と弱非線形性を考慮した水圧波から表面波への 換算方法について,海岸工学論文集, 第 39 巻, pp.171-175, 1992.

3)橋本典明 :ベイス型モデルを用いた方向スペクトルの推定， 港湾技術研究所報告書,第 29 巻,第 2 号,pp.97-125， 1987

4)橋本典明, 三井正雄, 河合弘泰, 児玉充由, 岩崎裕志 海 象計の方向スペク惟定における゙゙イズ法の適用性に関 する研究, 海洋開発論文集,第 26 巻,pp.1245-1250,2010 5)服部昌太郎 海岸工学, コ口ナ社, 1987 